\title{
POSTURAL ADJUSTMENTS OF ACTIVE YOUTHS IN PERTURBATION AND DUAL-TASK CONDITIONS
}

\author{
AJUSTES POSTURAIS DE JOVENS ATIVOS EM CONDIÇÕES DE PERTURBAÇÃO E TAREFA DUPLA
}

AJUSTES POSTURALES DE JÓVENES ACTIVOS EN CONDICIONES DE PERTURBACIÓN Y DOBLE TAREA

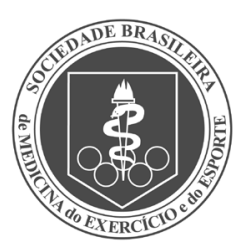

Original Article

Artigo Original Artículo Original
Victor Spiandor Beretta'

(Physical Education Professional)

Paulo Cezar Rocha Santos ${ }^{1,2}$

(Physical Education Professional)

Diego Alejandro Rojas Jaimes'

(Physical Education Professional)

Mayara Borkowske Pestana'

(Physical Education Professional)

Alejandra Maria Franco Jimenez 1 (Physical Education Professional)

Catarina Covolo Scarabottolo ${ }^{3}$

(Physical Education Professional)

Lilian Teresa Bucken Gobbi'

(Physical Education Professional)

1. Universidade Estadual Paulista (Unesp), Instituto de Biociências, Departments of Physical Educaion, Posture and Gait Studies Laboratory (LEPLO), Rio Claro, SP, Brazil.

2. Center for Human Movement

Sciences, University Medical Center Groningen, University of Groningen, Groningen, Netherlands.

3. Universidade Estadual Paulista (Unesp), Faculdade de Ciências e Tecnologia, Departments of Physical Educaion, Health and Physical Activity Group (GEAFS), Presidente Prudente, SP, Brazil.

\section{Correspondence:}

Victor Spiandor Beretta.

Universidade Estadual Paulista

(Unesp), Instituto de Biociências,

Departments of Physical Educaion, Posture and Gait Studies Laboratory (LEPLO), Avenue 24A, 1515, Bela Vista, Rio Claro, SP, Brazil. 13506-900. victor_beretta@hotmail.com

\begin{abstract}
Introduction: Cognitive components are necessary to maintain posture during external perturbations. However, few studies have investigated postural control when external perturbations are associated with a concomitant cognitive task (DT). Objectives: To analyze the behavior of reactive adjustments after perturbation with different intensities and displacements in active young adults; and to analyze the influence of DT on predictive and reactive adjustments in different perturbation conditions. Methods: Twenty-eight physically active young adults stood on an item of equipment that produced displacements of the base. Four experimental conditions were introduced in a single task (ST) and DT (cognitive-report how many times a pre-established number appeared in the audio): $1(5 \mathrm{~cm}$ and $10 \mathrm{~cm} / \mathrm{s}) ; 2(5 \mathrm{~cm}$ and $25 \mathrm{~cm} / \mathrm{s}) ; 3(12 \mathrm{~cm}$ and $10 \mathrm{~cm} / \mathrm{s})$ and $4(12 \mathrm{~cm}$ and $25 \mathrm{~cm} / \mathrm{s})$. Three attempts were carried out for each condition (total $=24)$. Center of pressure (COP) parameters were analyzed considering the following windows: predictive $(-250$ to $+50 \mathrm{~ms})$, reactive $1(+50$ to $+200 \mathrm{~ms})$ and reactive $2(+200$ to $+700 \mathrm{~ms})$, in comparison to the start of the CoP activity. One-way ANOVAs were performed to analyze predictive adjustments, while two-way ANOVAs with factor for task (STxDT) and condition ( $1 \times 2 \times 3 \times 4)$, with repeated measurements, were performed for the reactive adjustments. Results: One-way ANOVA (predictive) indicated that the subjects had higher CoP parameters in ST vs DT. In reactive adjustments 1 and 2, ANOVA indicated greater CoP parameters in condition 2 and 4 when compared to 1 and 3, and in the ST vs DT. The subjects took longer to recover stable position in conditions 1 and 3 than in conditions 2 and 4. Conclusion: Perturbation intensity has a greater influence on postural adjustments to maintain balance than on magnitude. Moreover, the association of cognitive tasks with external perturbation decreases CoP oscillation. Therefore, cognitive resources play an important role in postural control after perturbation. Level of evidence III; Study of nonconsecutive patients, with no "gold" standard applied uniformly.
\end{abstract}

Keywords: Young adult; Postural balance; Cognition.

\section{RESUMO}

Introdução: Componentes cognitivos são necessários para manter a postura nas perturbações externas. Porém, poucos estudos investigaram o controle postural quando perturbações externas são associadas à tarefa cognitiva concomitante (TD). Objetivo: Analisar o comportamento dos ajustes reativos após perturbação com diferentes intensidades e deslocamentos em adultos jovens ativos; e analisar a influência da TD nos ajustes preditivos e reativos em diferentes condições de perturbação. Métodos: Permaneceram em pé sobre um equipamento que provocou deslocamento da base de suporte 28 adultos jovens fisicamente ativos. Quatro condições experimentais foram realizadas em tarefa simples (TS) e TD (cognitiva-reportar quantas vezes um número preestabelecido apareceu no áudio): uma $(5 \mathrm{~cm}$ e $10 \mathrm{~cm} / \mathrm{s})$; duas $(5 \mathrm{~cm}$ e $25 \mathrm{~cm} / \mathrm{s})$; três $(12 \mathrm{~cm}$ e $10 \mathrm{~cm} / \mathrm{s})$ e quatro $(12 \mathrm{~cm}$ e $25 \mathrm{~cm} / \mathrm{s})$. Foram realizadas três tentativas para cada condição (total=24). Os parâmetros do centro de pressão (CoP) foram analisados em janelamentos: preditivo $(-250$ a $+50 \mathrm{~ms})$, reativo $1(+50 a+200 \mathrm{~ms})$ e reativo $2(+200$ a $+700 \mathrm{~ms})$, em relação ao início da atividade do COP. ANOVAs one-way foram realizadas para análise dos ajustes preditivos. Já para os ajustes reativos, foram realizadas ANOVAs two-way com fator para tarefa (TS XTD) e condição $(1 \times 2 \times 3 \times 4)$ com medidas repetidas. Resultados: ANOVA one-way (preditivo) apontou que os individuos apresentaram maiores parâmetros do COP na TS em relação à TD. Nos reativos 1 e2, a ANOVA apontou maiores parâmetros do CoP na segunda e na quarta condição quando comparada à primeira e à terceira, e na TS em relação às TD. Apresentaram maior tempo para recuperar a posição estável na primeira e na terceira condição em comparação à segunda e à quarta. Conclusão: A intensidade da perturbação influencia mais nos ajustes posturais para manutenção do equilíbrio do que a magnitude. Ainda, as tarefas cognitivas concomitantes à perturbação externa diminuem a oscilação do CoP. Com isso, recursos cognitivos possuem relevância no controle postural após perturbação. Nível de evidência III; Estudos de pacientes não consecutivos, sem padrão de referência "ouro" aplicado uniformemente.

Descritores: Adulto jovem; Equilíbrio postural; Cognição.

\section{RESUMEN}

Introducción:Los componentes cognitivos son necesarios para mantener la postura en perturbaciones externas. Sin embargo, pocos estudios investigaron el control postural cuando son asociadas perturbaciones a la tarea cognitiva concomitante (TD). Objetivo: Analizar el comportamiento de los ajustes reactivos después de una perturbación con diferentes intensidades y desplazamientos en adultos jóvenes activos; y analizar la influencia de la TD en ajustes predictivos y reactivos en diferentes 
condiciones de perturbación. Métodos: Veintiocho adultos jóvenes físicamente activos permanecieron en pie sobre un equipo que provocó desplazamiento de la base de soporte. Cuatro condiciones experimentales fueron realizadas en tareas simples (TS) y TD (cognitiva-reportar cuántas veces un número preestablecido apareció en el audio): una (5 cm y $10 \mathrm{~cm} / \mathrm{s}) ;$ dos $(5 \mathrm{~cm}$ y $25 \mathrm{~cm} / \mathrm{s})$; tres $(12 \mathrm{~cm}$ y $10 \mathrm{~cm} / \mathrm{s})$ y cuatro $(12 \mathrm{~cm}$ y $25 \mathrm{~cm} / \mathrm{s})$. Fueron realizadas tres tentativas para cada condición (total=24). Los parámetros del centro de presión (CoP) fueron analizados en ventanas: predictiva (-250 a +50 ms), reactiva 1 (+50 a +200 ms) y reactiva 2 (+200 a +700 ms) en relación al inicio de la actividad del CoP. Fueron realizadas ANOVAs one-way para aná-

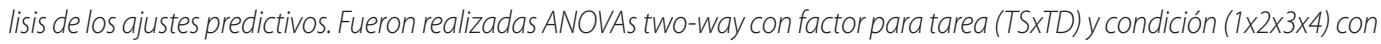
medidas repetidas para análisis de los ajustes reactivos. Resultados: ANOVA one-way (predictivo) mostró que los individuos presentaron parámetros mayores de CoP en TS con relación a TD. En los reactivos 1 y 2, ANOVA mostró parámetros del CoP en la segunda y cuarta condición cuando comparada a la primera y la tercera, y en la TS con relación a las TD. Presentaron tiempo mayor para recuperar la posición estable en la primera y tercera condición en comparación a la segunday la cuarta. Conclusión: La intensidad de perturbación influencia más en los ajustes posturales para mantenimiento del equilibrio que la magnitud. Además, las tareas cognitivas concomitantes a la perturbación externa disminuyen la oscilación del CoP. Con eso, los recursos cognitivos poseen relevancia en el control postural después de la perturbación. Nivel de evidencia III; Estudios de pacientes no consecutivos, sin estándar de referencia "oro" aplicado uniformemente.

Descriptores: Adulto joven; Balance postural; Cognición.

\section{INTRODUCTION}

Predictive and reactive adjustments are employed to maintain the posture in situations with external perturbation. ${ }^{1}$ Cognitive resources are needed to regulate the posture, ${ }^{2}$ such factors as divided attention into concomitant activities may generate difficulties in the balance performance. ${ }^{3}$ Thus, several studies have aimed to analyze the influence of the dual-task (DT) on postural control. DT, in this context, can be provided as concomitant motor tasks ${ }^{4}$ or as combined motor and cognitive task., ${ }^{5,6}$ Results regarding the influence of cognitive DT in postural control adjustments in young adults are contradictory. Rankin and colleagues (2000) $)^{(5)}$ indicated no difference for the muscular onset latency in the postural adjustments during DT, but that the amplitude of the muscular activity was affected. However, Yardley et al. (1999) ${ }^{6}$ evidenced that are no differences in body sway in situations with cognitive DT. Despite Rankin and colleagues $(2000)^{5}$ had performed perturbations with different velocities (between $20 \mathrm{~cm} / \mathrm{s}$ and $60 \mathrm{~cm} / \mathrm{s}$ ), they did not compare the postural responses in different conditions of external perturbation. Besides, the predictive adjustments were not investigated and the effect of DT are somewhat inconclusive, evidencing a gap in the understanding of the impact of different condition of perturbations in the postural control, mainly with a concomitant cognitive task.

Thus, the aims of this study were (i) to analyze the reactive postural adjustments in different conditions of perturbations in young adults physically active, and (ii) to verify the influence of DT on predictive and reactive adjustments in different perturbation conditions. We hypothesize to find, under high-intensity conditions, greater reactive adjustments (such as the greater center of pressure-CoP sway) than under low-intensity situations, regardless of the support base amplitude displacement. Furthermore, we expected that young adults physically active present greater CoP sway in predictive and reactive postural adjustments in DT compared to the single task (ST) condition, mainly in the perturbations with higher intensity.

\section{METHODS}

The study was conducted at Posture and Gait Studies Laboratory (LEPLO) - São Paulo State University, Rio Claro. Twenty-eight young adults physically active participated in the study. The exclusion criteria were: orthopedic impairments that prevented the performance of the protocol and use of any medication that could affect the balance. The individuals were informed about the procedures, and signed the inform allowing their participation in the experiment by signing the informed consent. This study was approved by the research ethics committee of the referred University (CAAE:52534316.1.0000.5465).

The experimental protocol consisted of the physical activity level determination through the habitual physical activity questionnaire $(\mathrm{HPA})^{7}$ and exposure to the postural perturbation test. For the postural perturbation task, the participant was asked to remain in a bipedal position on a $50 \times 50 \mathrm{~cm}(200 \mathrm{~Hz})$ force platform (AccuGait, Boston, MA). We designed the contour of the feet for each individual, to ensure the constant positioning in all trials. The force platform was positioned on the RC-Slide equipment (see BERETTA, $2017^{8}$ for more details). The RC-Slide was calibrated prior to the start of the evaluation of each participant to guarantee the intensity established in each condition. The participant suffered disruptions caused in the support base made by the displacement of the platform in the posterior direction in an unpredicted way. The duration of each trial was the 30s and the perturbation occurred within that period. To secure the participants'safety, all individuals were fitted with a harness attached to the ceiling. The system did not give any bodyweight support, also it did not constrain the body movement. Four experimental conditions of perturbations were established: 1) low displacement/low speed $(5 \mathrm{~cm}$ and $10 \mathrm{~cm} / \mathrm{s}) ; 2)$ low displacement/high speed $(5 \mathrm{~cm}$ and $25 \mathrm{~cm} / \mathrm{s}) ; 3)$ great displacement/low speed $(12 \mathrm{~cm}$ and $10 \mathrm{~cm} / \mathrm{s})$; and 4 ) great displacement/high speed $(12 \mathrm{~cm}$ and $25 \mathrm{~cm} / \mathrm{s})$. The experimental conditions were performed in ST and DT. In DT, simultaneously to the postural perturbation task, audio with random numbers of 0-9 was offered to the participant. The participant was instructed to pay attention to how many times a target number (previously established) appeared in the audio and, in the end, they should report the number of times they heard/identified the target number. As an example, in the sequence "1,6,8,5,4,3,7,1,8,1,9,5", in which the target number is "1", the answer should be "three times". Each participant made 24 trials, 3 for each perturbation condition and for each task (ST and DT), totally randomized.

The perturbation start was identified by an accelerometer (TrignoTM Wireless System-Delsys, Inc.) $(148.15 \mathrm{~Hz})$ placed on the force platform. CoP data were analyzed for in a window of 2000 ms before the perturbation until the end of the trial. The onset of CoP activity was determined when the displacement was greater than the mean plus two times the standard deviation of the baseline period (windowing between -500ms and -300ms). CoP parameters in the predictive adjustments were analyzed for a period between $-250 \mathrm{~ms}$ and $+50 \mathrm{~ms}$ in relation to the perturbation. ${ }^{9}$ The reactive adjustments were analyzed in two window fixtures: a) reactive1 between 
+50 and $+200 \mathrm{~ms}$; b) reactive 2 between +200 and $+700 \mathrm{~ms}$ in relation to the onset CoP activity. ${ }^{5,8,10}$ The parameters of the CoP analyzed in the anteroposterior (AP) and mediolateral (ML) directions in each windowing period were: displacement, range and mean velocity. ${ }^{11}$ In addition, the time to recover the stable position ${ }^{8}$ was analyzed and determined by the time between the onset of the CoP activity and the stabilization of the sway.

We run the statistic analysis at the SPSS 21.0 program (SPSS, Inc.). The significance level was maintained at 5\%. Regarding the CoP parameters in the predictive adjustments, we conducted one-way ANOVAs (STXDT). To the reactive adjustments, we performed two-way ANOVAs within factors for task (STXDT) and condition ( $1 \times 2 \times 3 \times 4)$ with repeated measurements. When interaction were indicated, we applied Bonferroni post hoc tests, with adjusted significance levels, to identify the differences.

\section{RESULTS}

Twenty-nine errors were observed during the DT trials. The major number error was indicated in situations of higher intensity perturbation, condition 2 and 4. (Table 1)

The results of the CoP are presented in sessions according to the windowing (predictive and reactive) in each task (DT and ST), and the time to recover the stable position presented along with the reactive2.

The ANOVA showed that young adults physically active presented greater CoP displacement and higher CoP mean velocity, both in ML direction, in ST when compared to DT. (Table 2)

The Bonferroni post hoc test indicated that the individuals presented higher AP-displacement, AP-range and AP-mean velocity of CoP, in conditions 2 and 4 compared to the condition $1(p=0.049)$ and 3 $(p=0.010)$. (Table 3$)$

Table 1. Mean and standard deviations of the demographic characteristics, the HPA questionnaire score and the DT error in each perturbation condition.

\begin{tabular}{c|c|c|c|c|c}
\hline & Sex & Age (years) & Height $(\mathbf{c m})$ & Body Mass (kg) & HPA (pts) \\
\hline $\mathrm{N}=28$ & $13 \mathrm{M} / 15 \mathrm{~F}$ & $23.86 \pm 3.05$ & $168.27 \pm 9.02$ & $64.43 \pm 8.39$ & $9.17 \pm 0.99$ \\
\hline Conditions & 1 & 2 & 3 & 4 & Total \\
\hline Error DT & $0.20 \pm 0.41$ & $0.40 \pm 0.67$ & $0.07 \pm 0.25$ & $0.30 \pm 0.53$ & $0.97 \pm 0.89$ \\
\hline DT=dual-tasks; HPA=habitual physical activity.
\end{tabular}

Table 2. Mean and standard deviations of predictive postural adjustments in postural perturbation with a single task and double task.

\begin{tabular}{c|c|c|c}
\hline \multirow{2}{*}{ CoP parameters } & \multicolumn{2}{|c|}{ Predictive } & \multirow{2}{*}{ Task effect } \\
\cline { 2 - 4 } & ST & DT & Ns \\
\hline AP-Displacement $(\mathrm{cm})$ & $0.56 \pm 0.44$ & $0.53 \pm 0.47$ & $\mathrm{~N}$ \\
\hline ML-Displacement $(\mathrm{cm})$ & $0.14 \pm 0.08$ & $0.13 \pm 0.09$ & $F_{(1,332)}=4.168 ; \mathrm{p}=0.041$ \\
\hline AP-Range $(\mathrm{cm})$ & $0.47 \pm 0.43$ & $0.44 \pm 0.46$ & $\mathrm{Ns}$ \\
\hline ML-Range $(\mathrm{cm})$ & $0.11 \pm 0.08$ & $0.10 \pm 0.09$ & $\mathrm{Ns}$ \\
\hline AP- Mean velocity $(\mathrm{cm} / \mathrm{s})$ & $1.83 \pm 1.46$ & $1.73 \pm 1.54$ & $\mathrm{~F}_{(1,332)}=4.168 ; \mathrm{p}=0.041$ \\
\hline ML- Mean velocity $(\mathrm{cm} / \mathrm{s})$ & $0.47 \pm 0.27$ & $0.43 \pm 0.31$ &
\end{tabular}

ANOVA revealed task by condition interaction (Figure 1), and task and condition main effects (Table 4). We will describe the differences regarding the main effects only for the variables that did not show interaction.

Concerning the interaction, the Bonferroni post hoc test indicated that the individuals presented higher AP-displacement and AP-mean velocity of COP in ST in conditions $1(p=0.048)$ and $4(p=0.004)$ when compared to DT. In addition, in condition 1, the individuals presented higher ML- displacement and ML-mean velocity of COP in ST than DT $(p=0.001)$. Furthermore, the individuals had a higher AP-displacement in condition 2 when compared to conditions 1 ( $p<0.001), 3(p<0.001)$ and 4 ( $p<0.001)$, in condition 4 in relation to conditions $1(p=0.003)$ and 3 ( $p<0.001$ ) and in condition 1 when compared to $3(p=0.007)$ in both ST and DT (Figure 1a). Still in both tasks, they presented higher ML-displacement in condition 2 in relation to conditions $1(p=0.001)$ and $3(p<0.001)$, and in condition 4 in relation to $3(p=0.001)$. Specifically to DT, subjects had a higher ML-displacement in condition 2 compared to 4 ( $p<0.001)$ and in condition 4 in relation to $1(p=0.001)$. In ST, they presented higher ML-displacement in condition 1 when compared to 3 $(p=0.010)$ (Figure 1b). Individuals, in ST and DT, had AP-mean velocity of CoP values in condition 2 than conditions 1 ( $p<0.001), 3(p<0.001)$ and 4 ( $p<0.001)$, in condition 4 in relation to conditions $1(p=0.003)$ and $3(p<0.001)$ and in condition 1 compared to 3 ( $p=0.007$ ) (Figure 1c). At the ML-mean velocity of CoP, individuals in ST and DT presented higher values in condition 2 compared to conditions $1(p=0.001)$ and $3(p<0.001)$, and in condition 4 compared to $3(p=0.001)$. In DT, they presented a greater ML-mean velocity in condition 2 compared to 4 $(p<0.001)$, and in condition 4 in relation to $1(p=0.001)$. Finally, still referring to the interaction, in ST, the individuals presented higher ML-mean velocity of CoP in condition 1 when compared to $3(p=0.010)$ (Figure 1d).

For the main effect of the condition, the individuals independent of the task presented greater AP and ML-range of the CoP in condition 2 than $1(p<0.001)$ and $3(p<0.001)$ and in condition 4 compared to 3 $(p=0.001)$. Finally, they presented a greater AP-range in condition $2 \mathrm{vs}$. $4(p<0.001)$ and in condition 3 vs. $1(p<0.001)$. (Table 4)

The Bonferroni post hoc test indicated that subjects had a longer time to recover the stable position in conditions 1 and 3 compared to conditions $2(p<0.001)$ and $4(p<0.001)$. (Table 4$)$

\section{DISCUSSION}

The present study aimed to analyze the influence of DT on postural adjustments in different perturbation conditions. Our hypotheses were partially confirmed. Young adults physically active presented greater CoP sway in the reactive adjustments, mainly in the more intense perturbation (velocity $=25 \mathrm{~cm} / \mathrm{s}$ ). In addition, they presented a longer time to recover the stable position in the conditions with lower speed, in both ST and DT. Unexpectedly, in ST, young adults physically active presented greater CoP sway in predictive and reactive adjustments compared to DT. The main findings are discussed according to each aim of the present study.

Table 3. Reactive postural adjustments in the $1^{\text {st }}$ window (reactive 1) in the simple and dual-task in all conditions.

\begin{tabular}{|c|c|c|c|c|c|c|c|c|c|c|}
\hline & \multicolumn{2}{|c|}{$1(5 \mathrm{~cm}-10 \mathrm{~cm} / \mathrm{s})$} & \multicolumn{2}{|c|}{$2(5 \mathrm{~cm}-25 \mathrm{~cm} / \mathrm{s})$} & \multicolumn{2}{|c|}{$3(12 \mathrm{~cm}-10 \mathrm{~cm} / \mathrm{s})$} & \multicolumn{2}{|c|}{$4(12 \mathrm{~cm}-25 \mathrm{~cm} / \mathrm{s})$} & \multicolumn{2}{|r|}{ Effects } \\
\hline & ST & DT & ST & DT & ST & DT & ST & DT & Task & Condition \\
\hline AP-Displ.(cm) & $3.41 \pm 1.85$ & $3.01 \pm 1.56$ & $3.81 \pm 1.85$ & $3.82 \pm 1.74$ & $3.13 \pm 1.74$ & $3.07 \pm 1.47$ & $4.14 \pm 1.90$ & $3.88 \pm 1.86$ & Ns & $F_{(3,331)}=7.783 ; p<0.001$ \\
\hline ML-Displ.(cm) & $0.28 \pm 0.22$ & $0.26 \pm 0.26$ & $0.26 \pm 0.20$ & $0.25 \pm 0.22$ & $0.24 \pm 0.24$ & $0.22 \pm 0.21$ & $0.27 \pm 0.19$ & $0.25 \pm 0.23$ & Ns & Ns \\
\hline AP-Range (cm) & $3.39 \pm 1.83$ & $3.00 \pm 1.53$ & $3.81 \pm 1.85$ & $3.81 \pm 1.73$ & $3.09 \pm 1.65$ & $3.04 \pm 1.45$ & $4.14 \pm 1.90$ & $3.87 \pm 1.86$ & Ns & $F_{(3,331)}=8.413 ; p<0.001$ \\
\hline ML-Range $(\mathrm{cm})$ & $0.23 \pm 0.21$ & $0.22 \pm 0.24$ & $0.21 \pm 0.19$ & $0.22 \pm 0.21$ & $0.20 \pm 0.22$ & $0.19 \pm 0.18$ & $0.23 \pm 0.18$ & $0.20 \pm 0.20$ & Ns & Ns \\
\hline AP-Vel. $(\mathrm{cm} / \mathrm{s})$ & $22.01 \pm 11.93$ & $19.44 \pm 10.05$ & $24.59 \pm 11.94$ & $24.62 \pm 11.20$ & $20.17 \pm 11.26$ & $19.78 \pm 9.49$ & $26.73 \pm 12.25$ & $25.01 \pm 12.01$ & Ns & $F_{(3,331)}=7.783 ; p<0.001$ \\
\hline ML-Vel. (cm/s) & $1.78 \pm 1.45$ & $1.68 \pm 1.66$ & $1.65 \pm 1.28$ & $1.64 \pm 1.41$ & $1.55 \pm 1.57$ & $1.45 \pm 1.32$ & $1.77 \pm 1.22$ & $1.59 \pm 1.48$ & Ns & Ns \\
\hline
\end{tabular}




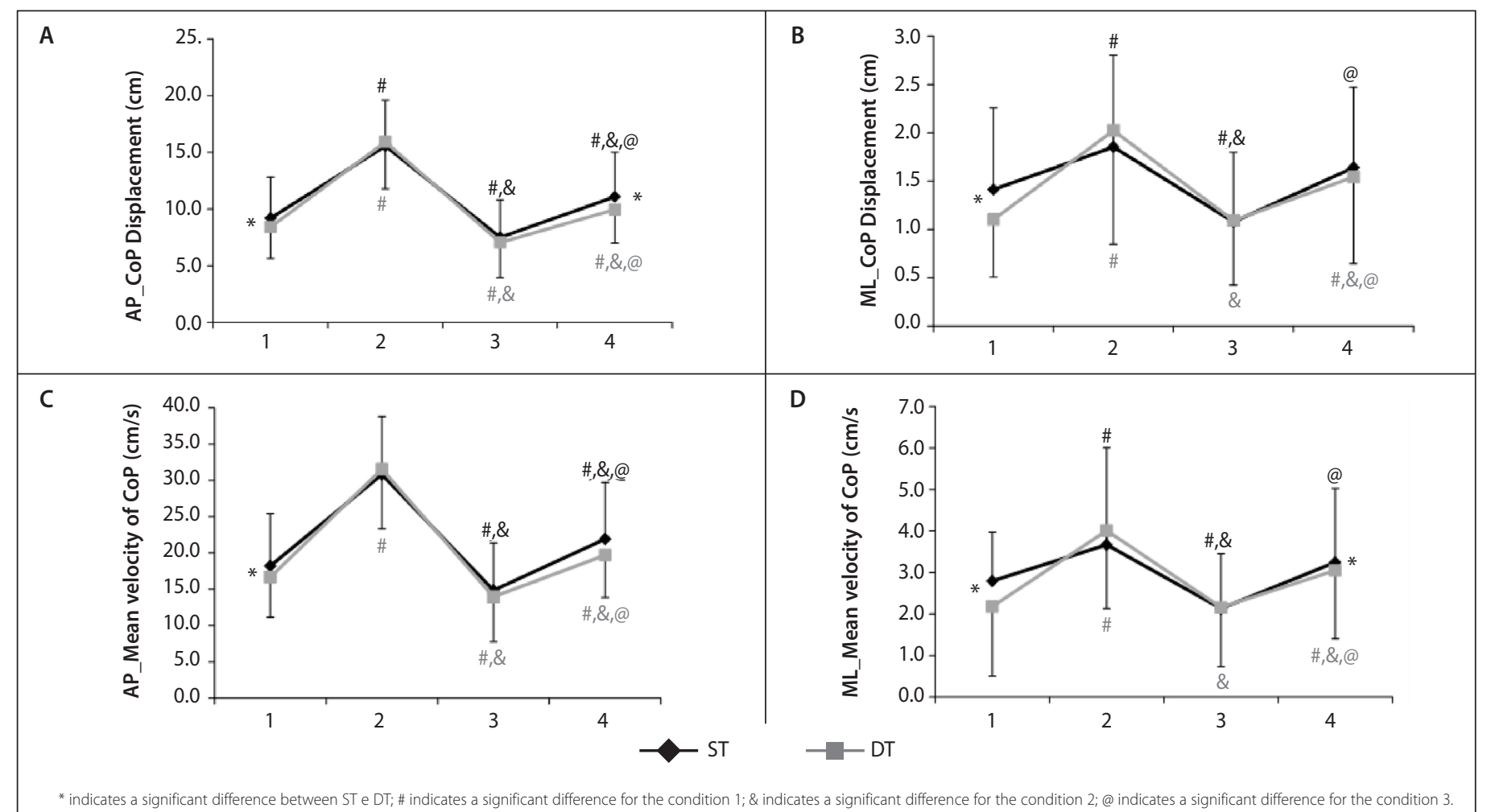

Figure 1. Interaction between task and condition for the: a) AP-Displacement; b) ML-Displacement; c) AP-Mean velocity; d) ML-Mean velocity.

Table 4. Reactive postural adjustments in the $2^{\text {nd }}$ window (reactive 2) and time to recover the stable position in the simple and dual-task in all conditions.

\begin{tabular}{|c|c|c|c|c|c|c|c|c|c|c|}
\hline & \multicolumn{2}{|c|}{$1(5 \mathrm{~cm}-10 \mathrm{~cm} / \mathrm{s})$} & \multicolumn{2}{|c|}{$2(5 \mathrm{~cm}-25 \mathrm{~cm} / \mathrm{s})$} & \multicolumn{2}{|c|}{$3(12 \mathrm{~cm}-10 \mathrm{~cm} / \mathrm{s})$} & \multicolumn{2}{|c|}{$4(12 \mathrm{~cm}-25 \mathrm{~cm} / \mathrm{s})$} & \multicolumn{2}{|c|}{ Effects } \\
\hline AP-Displ.(cm) & $9.20 \pm 3.63$ & $8.42 \pm 2.78$ & $15.56 \pm 4.04$ & $15.92 \pm 4.14$ & $7.50 \pm 3.31$ & $7.05 \pm 3.12$ & $11.07 \pm 3.94$ & $9.96 \pm 2.96$ & $F_{(1,332)}=6.438 ; p=0,012$ & $F_{(3,332)}=123.642 ; p<0.001$ \\
\hline ML-Displ.(cm) & $1.41 \pm 0.85$ & $1.10 \pm 0.59$ & $1.85 \pm 0.95$ & $2.02 \pm 1.18$ & $1.08 \pm 0.72$ & $1.09 \pm 0.67$ & $1.64 \pm 0.83$ & $1.54 \pm 0.90$ & Ns & $F_{(3,332)}=22.309 ; p<0.001$ \\
\hline AP-Range $(\mathrm{cm})$ & $6.17 \pm 2.86$ & $5.75 \pm 2.41$ & $10.76 \pm 2.76$ & $10.92 \pm 2.78$ & $4.44 \pm 1.99$ & $4.17 \pm 2.00$ & $6.69 \pm 2.55$ & $6.16 \pm 1.86$ & Ns & $F_{(3,332)}=154.949 ; p<0.001$ \\
\hline ML-Range $(\mathrm{cm})$ & $0.87 \pm 0.57$ & $0.73 \pm 0.49$ & $1.08 \pm 0.57$ & $1.11 \pm 0.65$ & $0.69 \pm 0.57$ & $0.66 \pm 0.38$ & $0.94 \pm 0.54$ & $0.95 \pm 0.64$ & Ns & $F_{(3,332)}=12.727 ; p<0.001$ \\
\hline ML-Vel. $(\mathrm{cm} / \mathrm{s})$ & $2.80 \pm 1.67$ & $2.18 \pm 1.18$ & $3.67 \pm 1.88$ & $4.01 \pm 2.33$ & $2.13 \pm 1.43$ & $2.16 \pm 1.33$ & $3.25 \pm 1.65$ & $3.05 \pm 1.78$ & Ns & $F_{(3,332)}=22.309 ; p<0.001$ \\
\hline Rec. Time (s) & $2.71 \pm 1.30$ & $2.66 \pm 0.90$ & $2.11 \pm 0.66$ & $2.16 \pm 0.80$ & $2.82 \pm 1.14$ & $2.75 \pm 1.26$ & $2.30 \pm 0.96$ & $2.32 \pm 0.68$ & Ns & $F_{(3,332)}=13.327 ; p<0.001$ \\
\hline
\end{tabular}

Displ. = displacement; Vel. = mean velocity; Rec $=$ recovery time; $\mathrm{AP}=$ anteroposterior; $\mathrm{ML}=$ =mediolateral; $\mathrm{ST}=$ simple task; $\mathrm{DT}=$ dual task; $\mathrm{Ns}=\mathrm{Not}$ significant.

Postural adjustments are essential to avoid falls after external perturbations, and the cerebral cortex seems to be involved in controlling these adjustments. ${ }^{2,12}$ The perturbations can be performed by external and unexpected ${ }^{9,13}$ or internal. ${ }^{9,14}$ mechanisms, causing postural adjustments such as muscle activity and CoP oscillation to modify their control patterns according to the perturbation. 10,13,15,16 In situations of high-intensity perturbation, the involvement of the hip muscles is necessary to maintain balance, while at low intensities control is mainly performed by the ankle muscles. ${ }^{17}$ But, there are controversial results regarding the intensity of the perturbation in the CoP parameters. ${ }^{13,16,18}$ Sarraf et al. (2014) ${ }^{18}$ found no differences in the peak of CoP displacement in high-intensity perturbations. However, our results corroborate partially with Babic et al. (2014) $)^{16}$ and Azzi et al (2017), ${ }^{13}$ showing an increase in CoP parameters, such as displacement, range and mean velocity in these situations. The increased CoP sway suggests an attempt to reestablish the postural control from the higher-intensity posture perturbation, increasing the AP and ML center of mass displacement within the stability limits of the support base. ${ }^{1}$

The increase in the magnitude and decrease in the onset latency of muscle activation are evidenced in perturbation with high intensities. ${ }^{13}$ Also, our study pointed out less time to recover a stable position in these situations. This behavior can be understood as a safety mechanism since in intense perturbation there is a need for a faster response to avoid falls. ${ }^{19}$ Thus, the integration of sensory-motor information needs to be efficient $t^{1,20}$ as observed in young adults physically active. Changes in postural responses in different magnitudes of perturbation are determined by an integration between the central and peripheral processes. ${ }^{20}$ The participation of cortical and subcortical structures in postural control, ${ }^{2}$ associated with late muscle response ${ }^{2}$ may represent changes in the organization and the magnitude of these responses after perturbation. ${ }^{21}$ Besides the influence of the intensity and displacement of the perturbation, the presence of concomitant cognitive task seems to alter the patterns of postural adjustments.

The worst performance in concomitant tasks may be due to limited ability to divide attention, ${ }^{3}$ inflexibility in reallocating cognitive resour$\mathrm{ces}^{22}$ and limited information processing capacity. ${ }^{23}$ Unexpectedly, our results revealed that young adults physically active had lower CoP oscillation in DT situations. The tasks employed in the present study present different requirements for the postural control (primary task) and cognition in the secondary task. Central processing and cognitive resources are required for postural control. ${ }^{2}$ Studies have revealed activation of subcortical areas by imaging the bipedal standing posture, 
activation of cortical areas in preparation to the perturbation (posterior parietal cortex and supplementary motor area) and response to external perturbation (prefrontal cortex). ${ }^{24,25}$ Considering that the prefrontal cortex is involved in the attention and planning of motor actions, it would be expected DT interference in decreasing the postural control performance. In contrast, the theoretical perspectives to explain can also be used to understand the positive DT influence on behavioral measurements of postural control.

Similar to our results, Huxhold et al. (2006) ${ }^{26}$ showed a decrease in CoP oscillation in older and young adults in DT situations. One possible explanation is in the difficulty of the concomitant cognitive task, being these positive changes in CoP observed in DT with less requirement. The results of this study advance the understanding of the DT interference to the lower cognitive requirement of the secondary task because the primary task required a high attention allocation. Individuals prioritized the primary task to the detriment of the secondary task. The characteristics of the primary task, unpredictability and the manipulation of the perturbation intensity and displacement, may explain the prioritization of this task and, therefore, there was no division of attention. In these situations, postural control can be generated more automatically with subcortical area contributions. ${ }^{27}$ In the more challenging postural tasks, this impairment is exacerbated, as a greater demand for cognitive resources is required, increasing the participation of cortical structures. ${ }^{26,27}$

Tasks that require greater attention demands change the postural adjustments in order to resist movement. ${ }^{28,29}$ This behavior known as mechanical stiffness maintains the balance through muscle tone and is involved with the mechanisms of anticipatory and reflex control.29,30 The decrease in stiffness may be related to the increase of the body oscillation, with this, the changes observed in the postural control during the execution of DT could be due to the use of this mechanism. ${ }^{29}$ These changes were observed in older adults during static postural control. ${ }^{29}$ However, our results suggest that this mechanism can also influence the postural control of young adults in situations with external perturbation, regardless of intensity and magnitude.

Some limitations were evidenced as a lack of electromyography and center of mass analysis. In addition, the cognitive task used seems to require less attention, so other DTs need to be investigated at the different intensities of the perturbation. Finally, other studies need to compare the influence of DT and different intensities of the perturbation in other populations as people with neurological disorders.

\section{CONCLUSION}

It is possible that the intensity of the perturbation influences more the postural adjustments to maintain CoP within stability limits than magnitude. Still, the realization of cognitive tasks concomitant to the postural control under external perturbation decreases the CoP parameters. With this, cognitive resources have relevance in the postural control after perturbation, being able to be related to stiffness mechanisms.

\section{ACKNOWLEDGMENT}

The author's thanks São Paulo Research Foundation (FAPESP) [grant number \#2016/00503-0] and CNPq (grant number \#306389/2013-4) for financial support.

All authors declare no potential conflict of interest related to this article

AUTHORS' CONTRIBUTIONS: Each author made significant individual contributions to this manuscript. VSB (0000-0002-4640-7733)*: conception, design, data collection, data analysis and interpretation, and writing of the manuscript; PCRS (0000-0001-7378-1897)*: conception, design, data collection, data analysis and interpretation, and writing of the manuscript; DARJ (0000-0002-4133-1653)*: data collection and writing of the manuscript; MBP (0000-0001-5986-5154)*: data collection and writing of the manuscript; AMFJ (00000002-2845-443X)*: data collection and analysis, and writing of the manuscript; CCS (0000-0003-4224-3396)*: data collection and writing of the manuscript; LTBG (0000-0003-39843403)*: conception, design, data interpretation, and writing of the manuscript. All authors approved the final version of the manuscript. *ORCID (Open Researcher and Contributor ID).

\section{REFERENCES}

1. Macpherson JM, Horak FB. Postura. In: Kandel ER, Schwarts JH, Jessell TM, Siegelbaum SA, Hudspeth AJ, editores. Princípios de neurociências. $5^{\circ}$ ed. Porto Alegre: AMGH, 2014; 811-832.

2. Jacobs JV, HorakFB. Cortical control of postural responses. J Neural Transm (Vienna). 2007;1 14(10):1339-48.

3. Jamet M, Deviterne D, Gauchard GC, Vançon G, Perrin PP. Age-related part taken by attentional cognitive processes in standing postural control in a dual-task context. Gait Posture 2007;25(2):179-84

4. De Lima AC, Toledo DR, Teixeira LA. Ajustes posturais são modulados pela complexidade da tarefa manual. Rev Bras Cineantrom Desemp Hum. 2009;11(4):400-7.

5. Rankin JK, Woollacott MH, Shumway-Cook A, Brown LA. Cognitive influence on postural stability: a neuromuscularanalysis in young and older adults. J Gerontol A BiolSci Med Sci. 2000;55(3):M112-9.

6. Yardley L, Gardner M, Leadbetter A, Lavie N. Effect of articulatory and mental tasks on postural control. Neuroreport. 1999;10(2):215-9

7. Florindo $A A$, Latorre MS. Validation and reliability of the Baecke questionnaire for the evaluation of habitual physical activity in adult men. Rev. Bras Med Esporte. 2003;9:121-28.

8. Beretta VS. Ajustes posturais sob perturbação externa em indivíduos com doença de Parkinson e neurologicamente sadios. 2017. 82 f. [Dissertação Mestrado em Ciências da Motricidade]; Universidade Estadual Paulista "Júlio de Mesquita Filho"; 2017

9. Santos MJ, Kanekar N, Aruin AS. The role of anticipatory postural adjustments in compensatory control of posture: 1. Electromyographic analysis. J Electromyogr Kinesiol. 2010;20(3):388-97.

10. Horak FB, Dimitrova D, Nutt JG. Direction-specific postural instability in subjects with Parkinson's disease. Exp Neurol. 2005;193(2):504-21.

11. Duarte M, Freitas SM. Revisão sobre posturografia baseada em plataforma de força para avaliação do equilíbrio. Rev Bras Fisioter. 2010;14(3):183-92

12. Mierau A, Hülsdünker T, Strüder HK. Changes in cortical activity associated with adaptive behavior during repeated balance perturbation of unpredictable timing. Front Behav Neurosci. 2015;9:272.

13. Azzi NM, Coelho DB, Teixeira LA. Automatic postural responses are generated according to feet orientation and perturbation magnitude. Gait Posture. 2017;57:172-6.

14. Piscitelli D, Falaki A, Solnik S, Latash ML. Anticipatory postural adjustments and anticipatory synergy adjustments: preparing to a postural perturbation with predictable and unpredictable direction. Exp Brain Res. 2017;235(3):713-30.

15. Henry SM, Fung J, Horak FB. EMG responses to maintain stance during multidirectional surface translations. J Neurophysiol. 1998;80(4):1939-50
16. Babič J, Petrič T, Peternel L, Šarabon N. Effects of supportive hand contact on reactive postura control during support perturbations. Gait Posture 2014;40(3):441-6.

17. Horak FB. Postural orientation and equilibrium: what do we need to know about neural control of balance to prevent falls? Age Ageing 2006;35(Suppl 2):ii7-11.

18. Sarraf TA, Marigold DS, Robinovitch SN. Maintaining standing balance by handrail grasping. Gait Posture 2014;39(1):258-64.

19. Visser JE, Carpenter MG, van der Kooij H, Bloem BR. The clinical utility of posturography. Clin Neurophysio 2008;119(11):2424-36.

20. Diener HC, Horak FB, Nashner LM. Influence of stimulus parameters on human postural responses. J Neurophysiol. 1988;59(6):1888-905

21. Kurtzer IL. Long-latency reflexes account for limb biomechanics through several supraspinal pathways. Front Integr Neurosci. 2015;8:99.

22. Franconeri SL, Alvarez GA, Cavanagh P. Flexible cognitive resources: competitive content maps for attention and memory. Trends Cogn Sci. 2013;17(3):134-41.

23. Marois R, Ivanoff J. Capacity limits of information processing in the brain. Trends Cogn. Sci. 2005;9:296-305.

24. Jahn K, Deutschländer A, Stephan T, Strupp M, Wiesmann M, Brandt T. Brain activation patterns during imagined stance and locomotion in functional magnetic resonance imaging. Neuroimage 2004;22(4):1722-31.

25. Mihara M, Miyai I, Hatakenaka M, Kubota K, Sakoda S. Role of the prefrontal cortex in human balance control. Neuroimage. 2008;43(2):329-36

26. Huxhold O, Li SC, Schmiedek F, Linderberg U. Dual-tasking postural control: Aging and the effects of cognitive demand in conjunction with focus of attention. Brain Res Bull. 2006;69(3):294-305.

27. Lacour M, Bernard-Demanze L, Dumitrescu M. Posture control, aging, and attention resources: Models and posture-analysis methods. Clinical Neurophysiol. 2008;38(6):411-21.

28. Winter DA, Patla AE, Prince F, Ishac M, Gielo-Perczak K. Stiffness control of balance in quiet standing. Neurophysiol. 1998;80(3):1211-21.

29. Kang HG, Lipsitz LA. Stiffness control of balance during quiet standing and dual task in older adults: The MOBILIZE Boston study. J Neurophysiol. 2010;104(6):3510-7.

30. Morasso PG, Schieppati M. Can Muscle Stiffness Alone Stabilize Upright Standing? J Neurophysiol. 1999;82(3):1622-6. 